UDK 577.1 : 61

ISSN 1452-8258

J Med Biochem 41: 100-107, 2022

Original paper

Originalni naučni rad

\title{
SSRP1 AFFECTS THE GROWTH AND APOPTOSIS OF GASTRIC CANCER CELLS THROUGH AKT PATHWAY
}

\author{
SSRP1 UTIČE NA RAST I APOPTOZU ĆELIJA RAKA ŽELUCA KROZ AKT SIGNALNI PUT
}

\author{
Guohua Jin, Ruihong Zhao, Jianguang Zhang, Tingting Cao, Tongyu Tang \\ Department of Gastroenterology, The First Hospital of Jilin University, Changchun, China
}

\section{Summary}

Background: We aimed to determine the SSRP1's potential influence on the apoptosis and proliferation of gastric cancer (GC) cells and its regulatory mechanism.

Methods: SSRP1 expression in GC cells and tissues was detected via quantitative reverse transcription-polymerase chain reaction ( $q R T-P C R$ ). The interrelation between clinicopathological characteristics of GC patients and SSRP1 expression was analysed via $\chi^{2}$ test, and the correlation between SSRP1 expression and overall survival rate was analysed using Kaplan-Meier survival analysis. After the knockdown of SSRP1 in AGS cells, the SSRP1 expression, colony formation ability, cell viability, cell cycle changes, apoptosis rate, and migration and invasion ability were detected through qRT-PCR, colony formation assay, CCK8 assay, flow cytometry and transwell test, respectively. Finally, the effects of down-regulation of SSRP1 on the expressions of phosphorylated-protein kinase B (p-AKT), Bcell lymphoma-2 (Bcl-2) and $\mathrm{Bcl}-2$ associated $\mathrm{X}$ protein (Bax) were explored using Western blotting.

Results: SSRP1 displayed a high expression in GC cells and tissues. SSRP1 expression was closely interrelated to the TNM stage, lymph node metastasis and tumour size. The survival rate of patients was markedly shorter in the high expression group than in the lower expression group. After the knockdown of SSRP1 in cells, the viability and colony formation ability of AGS cells were inhibited. In addition, the cell ratio in the G1 phase was increased, while that in the $S$ phase declined, and the cell invasion and migration were obviously weakened. It was found from Western blotting that the knockdown of SSRP1 could evidently suppress

\section{Kratak sadržaj}

Uvod: Naš cilj je bio da otkrijemo potencijalni uticaj SSRP1 na apoptozu i proliferaciju ćelija raka želuca (GC) i njegov regulatorni mehanizam.

Metode: Ekspresija SSRP1 u GC ćelijama i tkivima je detektovana kvantitativnom lančanom reakcijom polimeraze reverzne transkripcije (qRT-PCR). Odnos između kliničkopatoloških karakteristika pacijenata sa GC i ekspresije SSRP1 je analiziran pomoću Hi-kvadratnog testa $\left(\chi^{2}\right)$, a korelacija između ekspresije SSRP1 i ukupne stope preživljavanja pomoću Kaplan-Meier analize preživljavanja. Nakon obaranja SSRP1 u ćelijama AGS, ekspresija SSRP1, sposobnost formiranja kolonije, vitalnost ćelija, promene ćelijskog ciklusa, stopa apoptoze i sposobnost migracije i invazije su otkriveni pomoću qRT-PCR, testa formiranja kolonije, CCK8 testa, protočne citometrije i transvel testa, redom. Konačno, efekti smanjenja SSRP1 na ekspresije fosforilisane protein kinaze B (p-AKT), B-ćelijskog limfoma2 (Bcl-2) i Bcl-2 pridruženog Ks proteina (Bax) su ispitani pomoću Vestern blota.

Rezultati: SSRP1 je pokazao visoku ekspresiju u GC ćelijama i tkivima. Ekspresija SSRP1 je bila usko povezana sa stadijumom TNM, metastazama u limfnim čvorovima i veličinom tumora. Stopa preživljavanja pacijenata je bila znatno kraća u grupi sa visokom ekspresijom nego u grupi sa nižom ekspresijom. Nakon obaranja vrednosti SSRP1 u ćelijama, došlo je do inhibicije vitalnosti i sposobnosti formiranja kolonija AGS ćelija. Pored toga, povećana je elijska stopa u G1 fazi, dok je u S fazi opala, dok su invazija i migracija ćelija očigledno oslabljene. Vestern blot metodom je utvđeno da bi obarenje SSRP1 moglo očigled-

\footnotetext{
Address for correspondence:

Tongyu Tang, MD

Department of Gastroenterology, the First Hospital of Jilin University,

1 Xinmin Street, Changchun, Jilin, China

Phone: 860431-88782821

e-mail: tangty@jlu.edu.cn
} 
the protein levels of $\mathrm{Bcl}-2$ and $\mathrm{p}-\mathrm{AKT}$ but promote the protein expression of Bax, indicating that silencing SSRP1 can inhibit the proliferative capacity and increase the number of GC cells through inactivating the AKT signalling pathway. Conclusions: SSRP1 rose up in GC tissues and cells. Reduction of SSRP1 can inhibit the proliferative capacity and increase the number of GC cells through inactivating the AKT signalling pathway.

Keywords: SSRP1, gastric cancer, proliferation, apoptosis

\section{Introduction}

Gastric cancer (GC) is a frequently seen malignancy seriously threatening human health. According to the latest statistics, the morbidity rate of GC ranks 4th among all malignant tumours in the world, and its mortality rate has jumped to 3 rd place $(1,2)$. The 5 year survival rate of GC patients in China has dramatically risen with the early gastroscopy and prompt surgical intervention in recent years (3). However, the 5 -year survival rate of advanced GC remains low (4). Therefore, further uncovering the pathogenesis of GC for preventing the occurrence of GC and improving the prognosis is of great significance.

Structure-specific recognition protein 1 (SSRP1) was originally identified as a high-mobility group 1 (HMG1)-related DNA-binding protein in 1991, and its biological functions can be attributed to its HMG domain (5). SSRP1, a subgroup of histone chaperones, boosts chromatin transcription (FACT) complex and regulates most processes associated with chromatins, such as replication, DNA repair, and transcription (6-9). It is believed that SSRP1 dramatically influences the development and occurrence of tumours, and its expression is upregulated in such tumours as hepatocellular cancer (10), colorectal cancer (11), nasopharyngeal cancer (12) and glioma (13). Knockdown of SSRP1 in vitro can suppress the proliferative capacity of glioma U251 and U87 cells by inactivating the MAPK pathway (13) and reducing the growth of NSCLC cells (14). Nevertheless, the biological role and mechanism of SSRP1 in gastric cancers remain unclear.

To clarify SSRP1's function in GC and its mechanism of action, therefore, SSRP1 expression in GC cells and tissues was explored through a series of functional assays, and its effects on the proliferative capacity, apoptosis, invasion and migration of GC cells via the protein kinase $B(A K T)$ pathway were determined, thereby providing new ideas for the targeted clinical treatment of GC.

\section{Materials and Methods}

\section{Patients and tissue specimens}

A total of 40 paired GC specimens were surgically resected in our hospital. The patients had com- no potisnuti nivo proteina $\mathrm{Bcl}-2$ i p-AKT, ali bi promovisalo ekspresiju proteina Bak, ukazujući da smanjenje SSRP1 može inhibirati proliferativni kapacitet i povećati broj GC ćelija kroz inaktivaciju AKT signalnog puta.

Zaključak: SSRP1 je porastao u tkivima i ćelijama GC. Smanjenje SSRP1 može inhibirati proliferativni kapacitet i povećati broj GC ćelija kroz inaktivaciju AKT signalnog puta.

Ključne reči: SSRP1, rak želuca, proliferacija, apoptoza

plete clinicopathological data and follow-up data. Specimens receiving 5-min fast freezing in liquid nitrogen were reserved at $-80{ }^{\circ} \mathrm{C}$. The present research was reviewed and obtained approval of the Hospital Medical Ethics Committee, and the written informed consent was obtained from all participants.

\section{Cell culture and transfection}

AGS, MGC-803, FU97, BGC-823, GES-1 and SGC-7901 cells were cultured in 1640 medium from Invitrogen (Carlsbad, CA, USA) containing 10\% fetal bovine serum (FBS) provided by GIBCO/BRL (Rockville, MD, USA), $100 \mathrm{U} / \mathrm{mL}$ penicillin and 100 $\mathrm{mg} / \mathrm{mL}$ streptomycin from Beyotime (Shanghai, China) under $5 \% \mathrm{CO}_{2}$ at $37^{\circ} \mathrm{C}$. AGS cells undergone siRNA (GenePharma, Suzhou, China) or NC transfection using Lipofectamine 2000 transfection reagent (Invitrogen, Carlsbad, CA, USA) as per the guidance of the manufacturer si-SSRP1 sense: 5'-GCCAUGUCUACAAGUAUGATT-3', and antisense: 5'-UCAUACUUGUAGACAUGGCTT-3'.

\section{Quantitative reverse transcription-polymerase} chain reaction ( $q R T-P C R)$

RNAs underwent RT into cDNAs on GoScript RT System (Promega, Madison, WI, USA) by an Allin-One miRNA RT kit (GeneCopoeia, Rockville, MD, USA). Then SYBR Green human miRNA kit (GeneCopoeia, Rockville, MD, USA) and GoTaq qPCR Master Mix (Promega, Madison, WI, USA) were utilised for qRT-PCR. The procedures of thermal cycler were set below: $95^{\circ} \mathrm{C}$ for $10 \mathrm{~min},\left(95^{\circ} \mathrm{C}\right.$ for 30 s) $\times 40$ cycles, primer annealing at $55^{\circ} \mathrm{C}$ for $30 \mathrm{~s}$ and $72{ }^{\circ} \mathrm{C}$ for $30 \mathrm{~s}$. Each assay was repeated for 3 times.

\section{Western blotting}

The cells were harvested and lysed with $1 \times$ cell lysate from Cell Signaling Technology (Danvers, MA, USA) with phenylmethylsulfonyl fluoride (PMSF) (1 $\mathrm{mmol} / \mathrm{L}$ ) at $4{ }^{\circ} \mathrm{C}$ for $30-60 \mathrm{~min}$. Subsequent to $10-$ min centrifugation at $12,000 \mathrm{~g}$, the cytoplasmic protein samples were obtained, and bicinchoninic acid (BCA) protein test kit from Thermo Fisher Scientific (Waltham, MA, USA) was utilised for measurement of 
protein concentration. Then, total protein samples $(20-50 \mu \mathrm{g})$ were isolated via $10-12 \%$ sodium dodecyl sulphate-polyacrylamide gel electrophoresis (SDSPAGE) and transferred onto a polyvinylidene fluoride (PVDF) membrane from Millipore (Billerica, MA, USA). The membrane was blocked by $5 \%$ skim milk at room temperature for $2 \mathrm{~h}$, and undergone primary antibody $(1: 1,000)$ incubation at $4{ }^{\circ} \mathrm{C}$ nightlong. On the following day, TBS with $0.05 \%(v / v)$ Tween-20 (TBST) was utilised for rinsing the membrane, and it received 2 -h incubation with secondary antibodies jugated by horseradish peroxidase (1:5,000, Lianke Biotech Co., Ltd., Hangzhou, China) at indoor temperature. Following rinsing, the membrane was observed using an electrochemiluminescence (ECL) assay kit (PerkinElmer, Inc., Rockford, IL, USA) and Tanon 5500 gel imaging system from Tanon Science \& Technology (Shanghai, China).

\section{Detection of proliferative activity via cell counting} kit-8 (CCK8) test

Cells undergoing transfection were paved onto a ninety-six-well plate (1000 cells/well), and cell proliferation was measured once a day as per the manufacturer's instructions. In a word, each well was added with $10 \mu \mathrm{L}$ of CCK8 solution (KeyGen BioTECH, Nanjing, China) for 2 -h cell incubation at $37^{\circ} \mathrm{C}$. Finally, the solution was assessed at $450 \mathrm{~nm}$ via spectrophotometry. The assay was repeated for 3 times in each group.

\section{Colony formation experiment}

Cells receiving transfection were paved onto a 6 well plate (200 cells/well), cultivated for 2 weeks, fixed with paraformaldehyde and dyed by Giemsa dye. Then formed colonies were counted, and the colony formation rate in each plate was calculated. The assay was repeated for 3 times in each group.

Examination of cell cycle and apoptosis rate via flow cytometry

Following at least two hours of immobilisation in cold methanol, cells received RNase A/propidium iodide (PI) solution incubation. After that, the FACSCalibur system from Becton-Dickinson (Franklin Lakes, NJ, USA) was utilised for distribution assessment of cell cycle, and the proportion of cells in varying phases was detected via Modfit 2.0 software. Flow cytometry and Annexin V/PI dying (Life Technologies, CA, USA) were implemented for apoptotic cell determination. This test was implemented thrice, and findings were presented as mean \pm SD. The proportion of apoptotic cells was analysed using FlowJo7.6.1 software.

\section{Transwell assay}

The motility of tumour cells in vitro was assessed using chambers for Transwell migration from Corning (Corning, NY, USA) and those for invasion from BD Biosciences (Franklin Lakes, NJ, USA). Briefly, 200,000 cells containing siRNA or not were added into medium supplemented with $2 \% \mathrm{FBS}$, and the lower chamber was added with the medium with $10 \%$ FBS for $48 \mathrm{~h}$. Then cells migrating/invading the base of the upper membrane were dyed with $0.1 \%$ crystal violet dye. Next, the cells were counted in five fields stochastically chosen using a microscope.

\section{Statistical analysis}

Data were processed via Statistical Product and Service Solutions (SPSS) 20.0 software (IBM, Armonk, NY, USA). Metrical data were displayed by mean $\pm S D(\bar{x} \pm S D)$. Intergroup differences were processed through t-test and one-way analysis of variance (ANOVA). Comparison of enumeration data was implemented using $\chi^{2}$ test. Survival curves were plotted using the Log-rank test (Kaplan-Meier method). $\mathrm{P}<0.05$ reflected statistically significant differences.

\section{Results}

SSRP1 displayed a high expression in GC tissues and cells

It was found from qRT-PCR that SSRP1 expression rose up in $40 \mathrm{GC}$ tissues compared with that in para-carcinoma normal ones (Figure 1A). SSRP1 expression was further detected in GES-1 as well as AGS, FU97, MGC-803, BGC-823 and SGC-7901. It was discovered that SSRP1 expression rose in GC cell lines, and it showed the highest value in AGS cell lines, so AGS cell lines were selected for subsequent knockdown assay (Figure 1B). According to the median expression of SSRP1, the patients were allocated into high- and low-expression groups, and the interrelations ofSSRP1 expression with clinical and pathological features of patients was further analysed. The results revealed that the patients in the high-expression group displayed a larger tumour size and advanced TNM stage, and are often accompanied by lymph node metastasis, showing statistically significant differences $(\mathrm{P}<0.05)$ (Table $\mathrm{I})$. Besides, the Kaplan-Meier survival curves were analysed. It was confirmed that patients in the high-expression group had a lower survival rate relative to that in the lowexpression group $(\mathrm{HR}=2.3980, \mathrm{P}=0.0369)$, indicating that SSRP1 predicts the unfavourable prognosis of GC patients. The above findings demonstrate that SSRP1 is highly expressed in GC patients, and it can affect the TNM stage, lymph node metastasis and tumour size of GC patients, indicating a poor prognosis. 


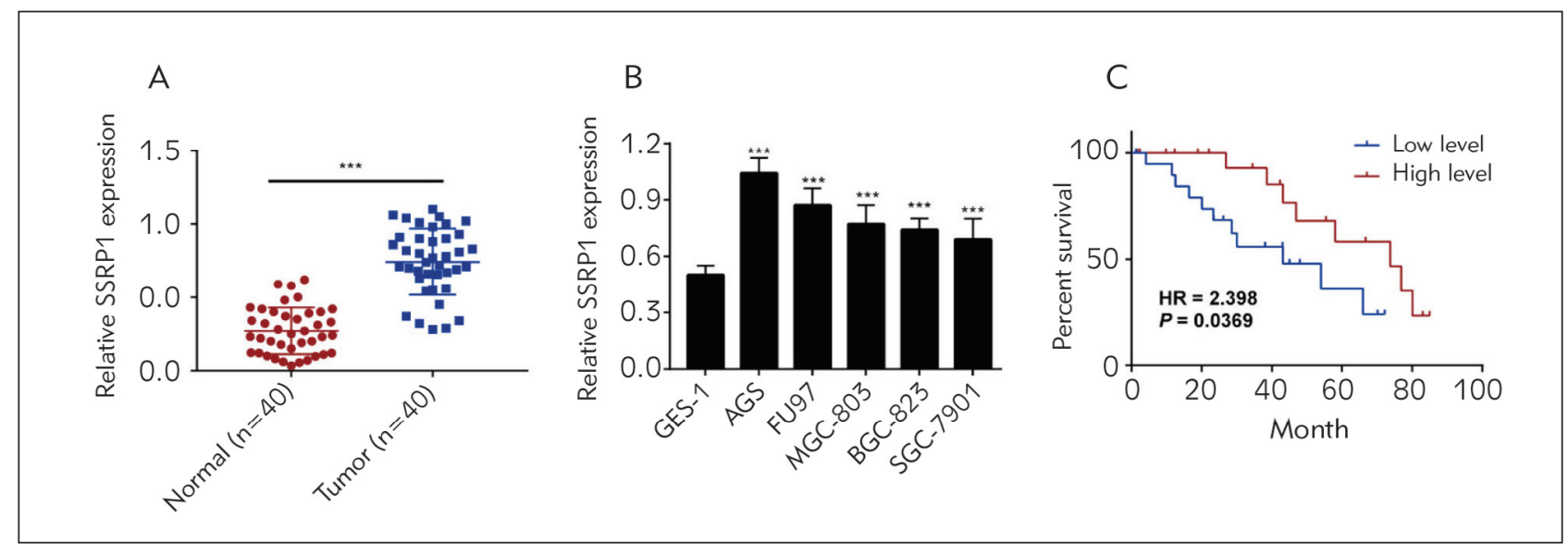

Figure 1 SSRP1 displays high expressions in GC cells and tissues. (A) It is found from qRT-PCR that SSRP1 expression obviously rose in 40 cases of GC tissues relative to that in para-carcinoma normal tissues. (B) The expression of SSRP1 is detected in GES-1 as well as AGS, FU97, MGC-803, BGC-823 and SGC-7901. (C) Kaplan-Meier survival analysis. Patients had a lower survival rate in the high-expression group relative to that in the low-expression group.

Table I Relations of SSRP1 expression with clinical and pathological features in GC patients $(n=40)$.

\begin{tabular}{|c|c|c|c|c|}
\hline \multirow{2}{*}{$\begin{array}{c}\text { Clinicopathologic } \\
\text { features }\end{array}$} & \multirow{2}{*}{$\begin{array}{l}\text { Number } \\
\text { of cases }\end{array}$} & \multicolumn{2}{|c|}{ SSRP1 expression } & \multirow[b]{2}{*}{ P-value } \\
\hline & & $\begin{array}{c}\text { Low } \\
(n=20)\end{array}$ & $\begin{array}{c}\text { High } \\
(n=20)\end{array}$ & \\
\hline Age (years) & & & & 0.752 \\
\hline$\leq 60$ & 19 & 10 & 9 & \\
\hline$>60$ & 21 & 10 & 11 & \\
\hline Gender & & & & 0.749 \\
\hline Male & 23 & 11 & 12 & \\
\hline Female & 17 & 9 & 8 & \\
\hline Tumour size & & & & $0.022 *$ \\
\hline$\leq 5 \mathrm{CM}$ & 15 & 11 & 4 & \\
\hline$>5 \mathrm{CM}$ & 25 & 9 & 16 & \\
\hline TNM stage & & & & $0.027 *$ \\
\hline$I+I I$ & 19 & 13 & 6 & \\
\hline III+IV & 21 & 7 & 14 & \\
\hline $\begin{array}{c}\text { Tumour } \\
\text { differentiation }\end{array}$ & & & & 0.113 \\
\hline Well/Moderate & 21 & 13 & 8 & \\
\hline Poor & 29 & 17 & 12 & \\
\hline $\begin{array}{l}\text { Lymph node } \\
\text { metastasis }\end{array}$ & & & & $0.004 *$ \\
\hline Absent & 19 & 14 & 5 & \\
\hline Present & 21 & 6 & 15 & \\
\hline \multicolumn{5}{|l|}{ Distant metastasis } \\
\hline Positive & & 11 & 8 & 0.342 \\
\hline Negative & & & 9 & 12 \\
\hline
\end{tabular}

\section{Knockdown of SSRP1 inhibited GC cell proliferation}

To explore SSRP1's role in GC development, AGS cell lines were further selected for knockdown assay and whether changes in SSRP1 affect GC cells was explored. QRT-PCR findings ascertained that SSRP1 mRNA expression dropped obviously after AGS cells were transfected with si-SSRP1 (Figure 2A). Then SSRP1's impact on AGS cell activity was assessed. It was unveiled from the CCK8 assay showed that cell activity was obviously weakened after knockdown of SSRP1 in contrast to that in the control group (Figure $2 B$ ). According to the colony formation assay, the capacity of AGS cells treated with siRNA to form colonies also became weaker (Figure 2C), implying that knocking down SSRP1 impedes GC cells to proliferate.

SSRP1 influenced GC cells to proliferate and their apoptosis by impeding the AKT signaling pathway

SSRP1's impacts on the cycle and apoptosis of AGS cells were explored using flow cytometry. As shown in Figure $3 \mathrm{~A}$, at $48 \mathrm{~h}$ after treatment of AGS cells with siRNA, cell proportion became larger in the G1 phase but smaller in the S phase, confirming that knockdown of SSRP1 can inhibit the transition of the G1/S phase. In addition, it was found from flow cytometry that the apoptosis rate rose markedly after the knockdown of SSRP1 (Figure 3B). As a classical signal transduction pathway, the AKT pathway is implicated in apoptosis and proliferation. Furthermore, the results of Western blotting manifested that knockdown of SSRP1 could suppress the protein expressions of phosphorylated AKT ( $p-A K T)$ and B-cell lymphoma-2 (Bcl-2), but evidently promote Bax protein expression (Figure $3 C \& 3 D$ ), indicating that silencing SSRP1 may inhibit GC cells from proliferating and promoting their apoptosis through the AKT signalling pathway. 

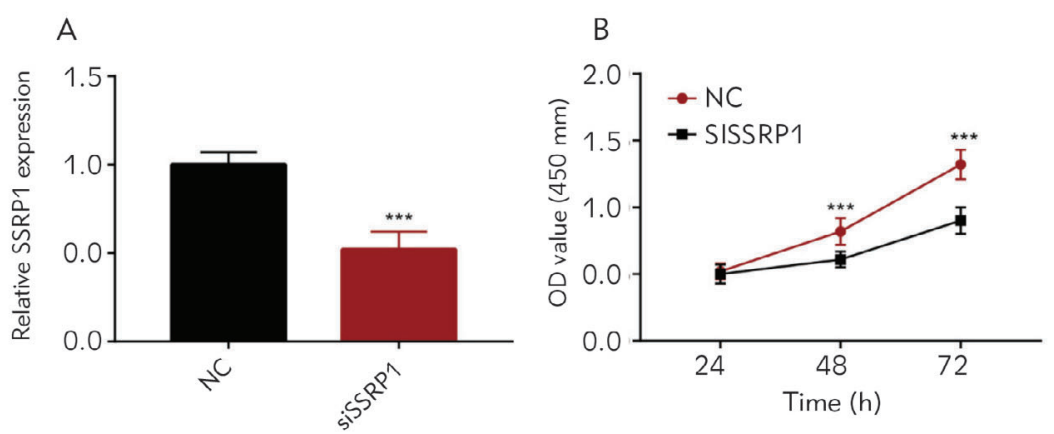

C

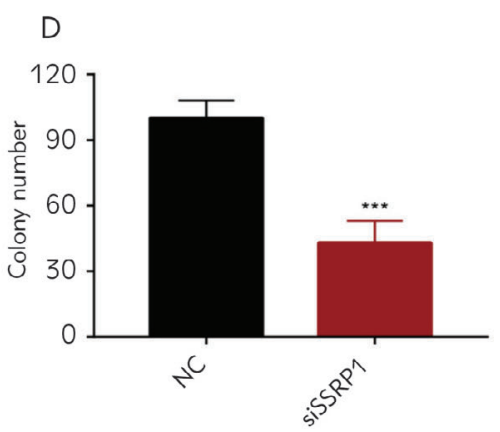

Figure 2 Decreasing SSRP1 impedes GC cells to proliferate. (A) QRT-PCR findings reveal that the mRNA expression of SSRP1 is obviously suppressed by knockdown of SSRP1 at $48 \mathrm{~h}$ after AGS cells are transfected with siRNA. (B) The results of the CCK8 assay show that the AGS cell viability declines after the knockdown of SSRP1. (C) Colony formation assay findings show that the colony formation ability of AGS cells becomes weaker after the knockdown of SSRP1.

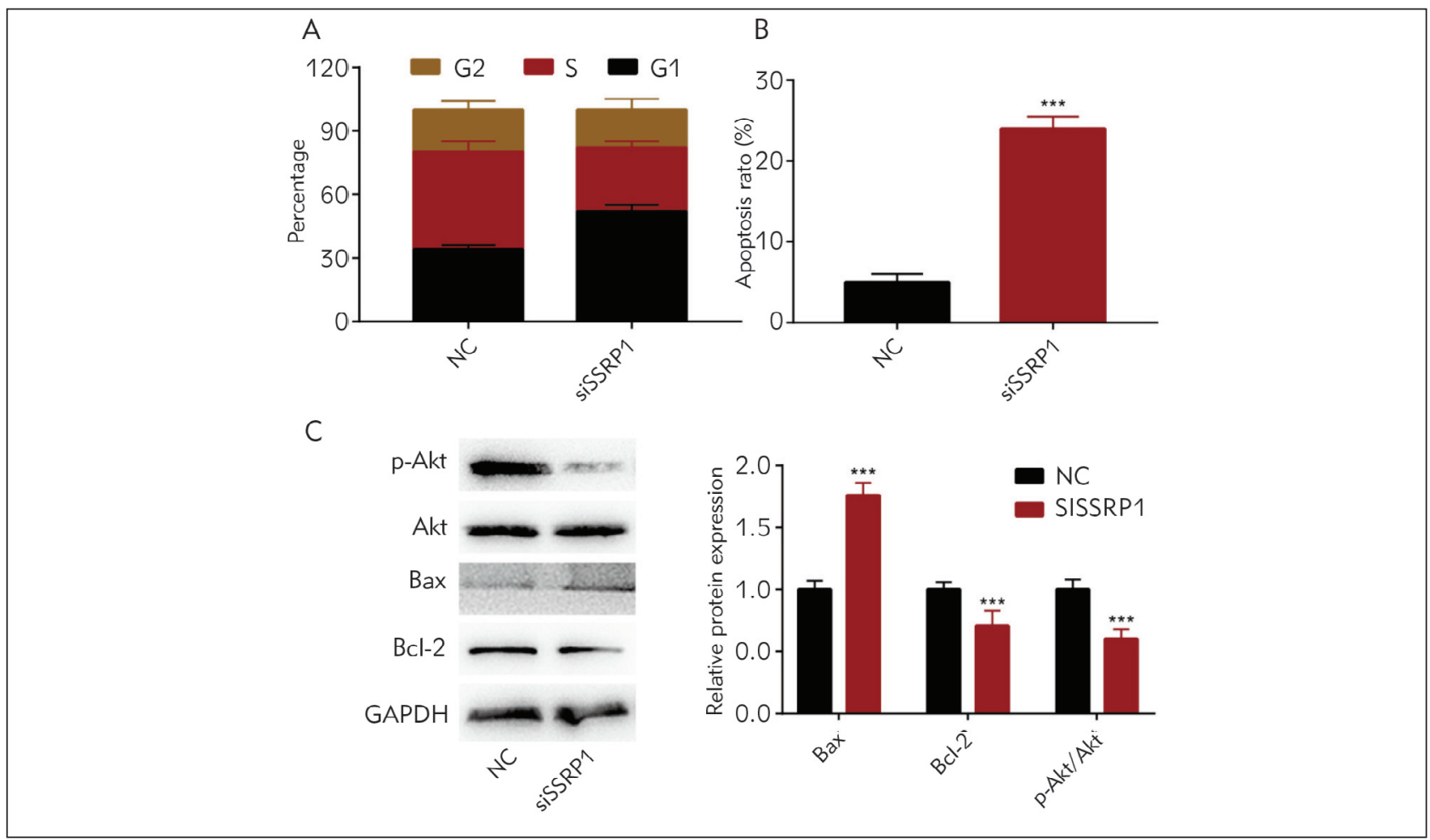

Figure 3 SSRP1 affects GC cells to proliferate and their apoptosis via impeding the AKT signalling pathway. (A) Flow cytometry findings manifest that cell proportion rises in the G1 phase and declines in the S phase, and no significant changes are found in cell proportion in the G2 phase. (B) Flow cytometry findings manifest that the apoptosis rate rises markedly after the knockdown of SSRP1. (C \& D) Western blotting results show that knockdown of SSRP1 can reduce the expressions of p-AKT and Bcl-2 proteins but increase the protein expression of Bax. 


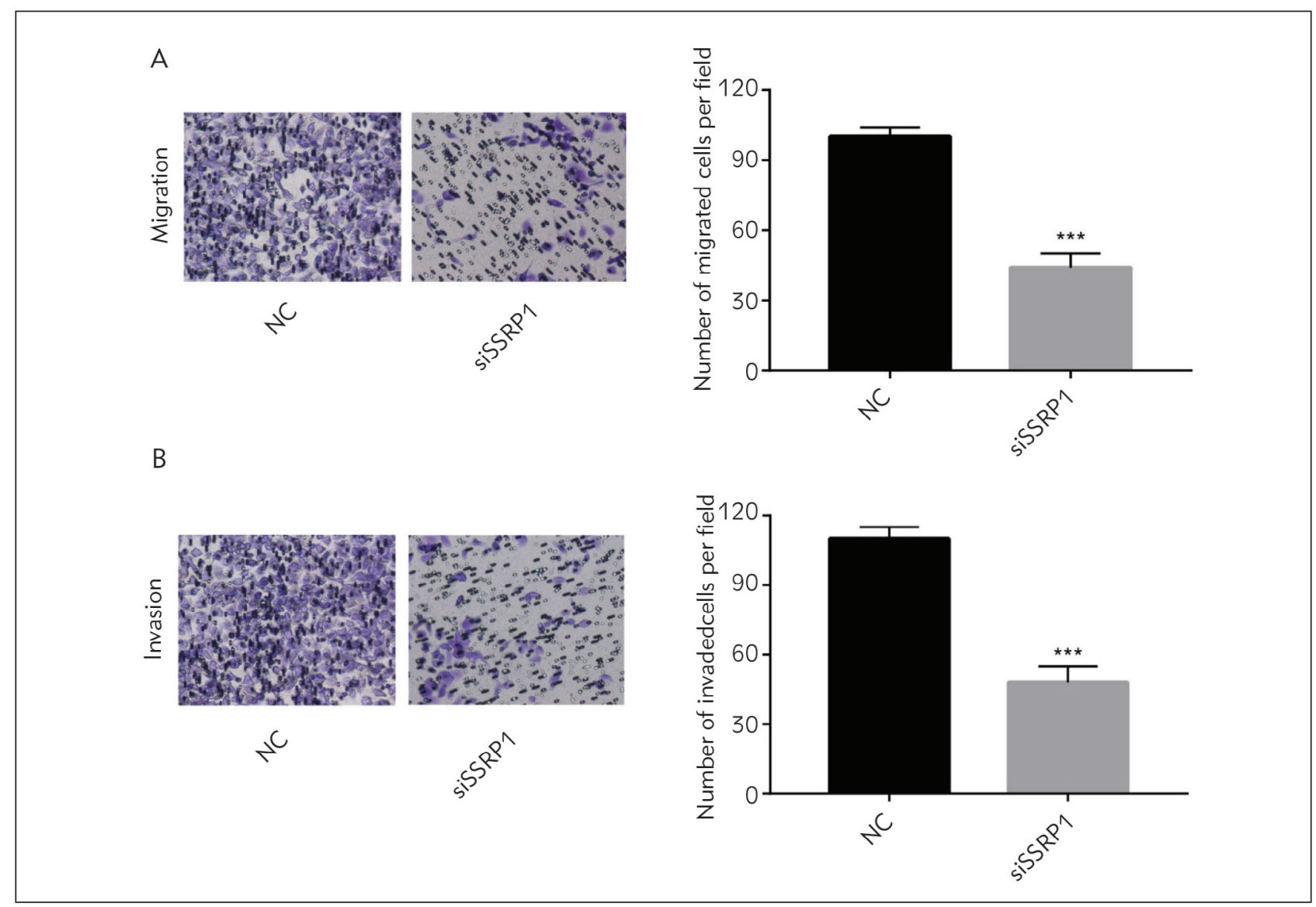

Figure 4 Down-regulation of SSRP1 suppresses GC cells to migrate and invade. (A \& B) Transwell assay findings show that after reducing SSRP1, the AGS cell migration and invasion capacities remarkably decline.

Down-regulation of SSRP1 suppressed GC cells to migrate and invade

As confirmed above, down-regulation of SSRP1 can impede GC cells to proliferate and promote their apoptosis. Then, SSRP1's influences on the GC cells' abilities to migrate and invade were further explored. Transwell assay findings showed that after SSRP1 knockdown, the cell migration and invasion ability remarkably declined (Figure $4 A \& 4 B$ ). Thus, it can be inferred that decreasing SSRP1 can impair the migration and invasion capacities of GC cells.

\section{Discussion}

It is reported that SSRP1, a subunit of histone chaperone protein FACT, can destroy the nucleosomes and histone substitutes $(15,16)$. Moreover, it is implicated in DNA damage repair and replication as well as cell proliferation and apoptosis $(14,17)$. In the current research, it was disclosed that SSRP1 rose in GC tissues and cells, consistent with previous studies on cancers, including NSCLC (14), breast cancer $(18,19)$ and liver cancer $(10)$. The survival rate of patients was lower in the high-expression group than in the low-expression group, indicating that highly expressed SSRP1 predicts the unfavourable prognosis of $\mathrm{GC}$ patients. Additionally, the results of a series of in vitro experiments confirmed that knockdown of SSRP1 could inhibit the vitality, colony formation ability and cell cycle transition of GC cells and induce apoptosis, and may also suppress cell migration and invasion.

SSRP1 is a key regulatory factor for keeping normal DNA replication because it is related to MCM helicase and can promote the unwinding activity of MCM helicase DNA on the nucleosome template $(20,21)$. Breaking the FACT-MCM complex can hinder the beginning of DNA replication. Inhibiting SSRP1 can suppress cells to grow and hamper the Sphase cell cycle progression owing to suppression on the replication fork advancement (20). Proliferation signals accompanied by enhanced DNA replication are the markers for cancer cells (22). In this study, it was found that decreasing SSRP1 repressed the viability and colony formation ability of GC cells, which is a characteristic feature of GC cells.

In this study, it was confirmed that SSRP1 played a role in regulating $G C$ cells to proliferate and regu- 
lated their cycle, apoptosis, invasion, and migration capacities. It was unveiled that knockdown of SSRP1 could lead to cell cycle arrest and induce apoptosis. Moreover, after the knockdown of SSRP1, the protein expression of Bcl-2 could be inhibited, whereas that of Bax could be promoted. During the progression of GC, metastasis is the fatal event, so early diagnosis of highly metastatic primary tumours is of important significance for the treatment and prognosis of patients. In this study, the findings revealed that SSRP1 knockdown impeded GC cells to migrate and invade. In addition, it is reported that SSRP1 is implicated in the classical PI3K/AKT signalling pathway and affects the apoptosis and proliferation of colon cancer cells via the AKT pathway (23). As the main signalling pathway in the downstream of many growth factor receptors, a classical signalling pathway related to cell apoptosis and survival, the PI3K/AKT pathway, is the most active signalling pathway in human tumours. Moreover, the PI3K/AKT pathway facilitates the proliferation and malignant transformation and impedes tumour cell apoptosis by phosphorylating PI3K and AKT proteins $(24,25)$. Serine/threonine kinase AKT, classified into AKT1-3, is a key PI3K signal transduc-

\section{References}

1. Liang D, Liang S, Jin J, Li D, Shi J, He Y. Gastric cancer burden of last 40 years in North China (Hebei Province): A population-based study. Medicine (Baltimore) 2017; 96: e5887.

2. Siegel RL, Miller KD, Jemal A. Cancer Statistics, 2017. CA Cancer J Clin 2017; 67: 7-30.

3. Hamashima C, Shabana M, Okada K, Okamoto M, Osaki Y. Mortality reduction from gastric cancer by endoscopic and radiographic screening. Cancer Sci 2015; 106: 1744-9.

4. Di L, Wu H, Zhu R, Li Y, Wu X, Xie R, et al. Multi-disciplinary team for early gastric cancer diagnosis improves the detection rate of early gastric cancer. Bmc Gastroenterol 2017; 17: 147.

5. Rottgers K, Krohn NM, Lichota J, Stemmer C, Merkle T, Grasser KD. DNA-interactions and nuclear localisation of the chromosomal HMG domain protein SSRP1 from maise. Plant J 2000; 23: 395-405.

6. Kumari A, Mazina OM, Shinde U, Mazin AV, Lu H. A role for SSRP1 in recombination-mediated DNA damage response. J Cell Biochem 2009; 108: 508-18.

7. Birch JL, Tan BC, Panov KI, Panova TB, Andersen JS, Owen-Hughes TA, et al. FACT facilitates chromatin transcription by RNA polymerases I and III. Embo J 2009; 28: 854-65.

8. Orphanides G, Wu WH, Lane WS, Hampsey M, Reinberg $D$. The chromatin-specific transcription elongation factor FACT comprises human SPT16 and SSRP1 proteins. Nature 1999; 400: 284-8. tion factor in mammals. Numerous studies have unravelled that the $\mathrm{PI3K} / \mathrm{AKT}$ pathway can promote GC cells to proliferate and invade $(26,27)$. In this study, therefore, the involvement of the AKT pathway in alterations of GC cell proliferation and apoptosis following interference with SSRP1 was explored. The findings manifested that knockdown of SSRP1 reduced the expression of $\mathrm{P}-\mathrm{AKT}$, indicating that SSRP1 regulates GC cell proliferation, cycle, apoptosis, invasion and migration via activating the AKT pathway.

\section{Conclusion}

Knockdown of SSRP1 affects GC cells to proliferate and their apoptosis through the AKT pathway, which provides a new possible therapeutic strategy and diagnostic target for GC.

\section{Conflict of interest statement}

The authors reported no conflict of interest regarding the publication of this article.

9. Zhang W, Zeng F, Liu Y, Shao C, Li S, Lv H, et al. Crystal Structure of Human SSRP1 Middle Domain Reveals a Role in DNA Binding. Sci Rep 2015; 5: 18688.

10. Ding $Q$, He K, Luo T, Deng $Y$, Wang $H$, Liu $H$, et al. SSRP1 Contributes to the Malignancy of Hepatocellular Carcinoma and Is Negatively Regulated by miR-497. Mol Ther 2016; 24: 903-14.

11. Wu W, He K, Guo Q, Chen J, Zhang M, Huang K, et al. SSRP1 promotes colorectal cancer progression and is negatively regulated by miR-28-5p. J Cell Mol Med 2019; 23: 3118-29.

12. Gao L, Xiong X. MiR-223 inhibits the proliferation, invasion and EMT of nasopharyngeal carcinoma cells by targeting SSRP1. Int J Clin Exp Pathol 2018; 11: 4374-84.

13. Liao J, Tao X, Ding Q, Liu J, Yang X, Yuan FE, et al. SSRP1 silencing inhibits the proliferation and malignancy of human glioma cells via the MAPK signaling pathway. Oncol Rep 2017; 38: 2667-76.

14. Dermawan JK, Gurova K, Pink J, Dowlati A, De S, Narla $G$, et al. Quinacrine overcomes resistance to erlotinib by inhibiting FACT, NF-kappaB, and cell-cycle progression in non-small cell lung cancer. Mol Cancer Ther 2014; 13: 2203-14.

15. Takahata S, Yu Y, Stillman DJ. FACT and Asf1 regulate nucleosome dynamics and coactivator binding at the $\mathrm{HO}$ promoter. Mol Cell 2009; 34: 405-15.

16. Tsunaka Y, Fujiwara Y, Oyama T, Hirose S, Morikawa K. Integrated molecular mechanism directing nucleosome reorganisation by human FACT. Genes Dev 2016; 30: 673-86. 
17. Gao XJ, Feng JX, Zhu S, Liu XH, Tardieux I, Liu LX. Protein Phosphatase 2C of Toxoplasma Gondii Interacts with Human SSRP1 and Negatively Regulates Cell Apoptosis. Biomed Environ Sci 2014; 27: 883-93.

18. Koman IE, Commane M, Paszkiewicz G, Hoonjan B, Pal S, Safina A, et al. Targeting FACT complex suppresses mammary tumorigenesis in Her2/neu transgenic mice. Cancer Prev Res (Phila) 2012; 5: 1025-35.

19. Fleyshman D, Prendergast L, Safina A, Paszkiewicz G, Commane M, Morgan K, et al. Level of FACT defines the transcriptional landscape and aggressive phenotype of breast cancer cells. Oncotarget 2017; 8: 20525-42.

20. Abe T, Sugimura K, Hosono Y, Takami Y, Akita M, Yoshimura A, et al. The histone chaperone facilitates chromatin transcription (FACT) protein maintains normal replication fork rates. J Biol Chem 2011; 286: 30504 12.

21. Zeng SX, Li Y, Jin Y, Zhang Q, Keller DM, McQuaw CM, et al. Structure-specific recognition protein 1 facilitates microtubule growth and bundling required for mitosis. Mol Cell Biol 2010; 30: 935-47.
22. Hanahan D, Weinberg RA. Hallmarks of cancer: the next generation. Cell 2011; 144: 646-74.

23. Wang Q, Jia S, Jiao Y, Xu L, Wang D, Chen X, et al. SSRP1 influences colorectal cancer cell growth and apoptosis via the AKT pathway. Int J Med Sci 2019; 16: 1573-82.

24. Laplante M, Sabatini DM. mTOR signaling in growth control and disease. Cell 2012; 149: 274-93.

25. Mabuchi S, Kuroda H, Takahashi R, Sasano T. The $\mathrm{PI3K} / \mathrm{AKT} / \mathrm{mTOR}$ pathway as a therapeutic target in ovarian cancer. Gynecol Oncol 2015; 137: 173-9.

26. Lu Y, Li L, Wu G, Zhuo H, Liu G, Cai J. Effect of PI3K/Akt Signaling Pathway on PRAS40Thr246 Phosphorylation in Gastric Cancer Cells. Iran J Public Health 2019; 48: 2196-204.

27. Hao NB, Tang B, Wang GZ, Xie R, Hu CJ, Wang SM, et al. Hepatocyte growth factor (HGF) upregulates heparanase expression via the PI3K/Akt/NF-kappaB signaling pathway for gastric cancer metastasis. Cancer Lett 2015; 361: 57-66. 